
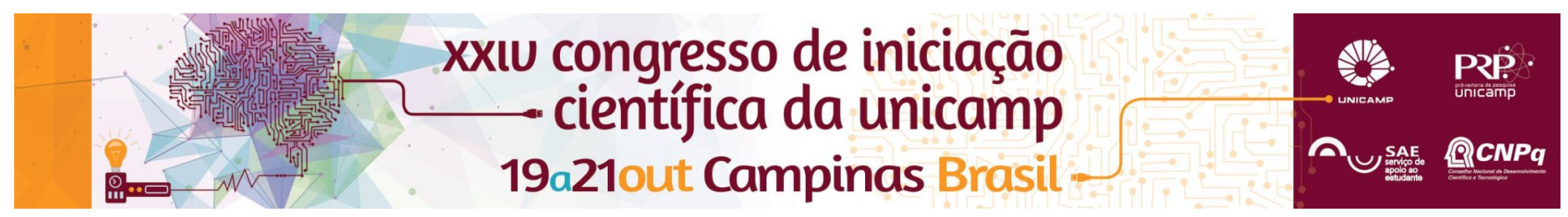

\title{
Montagem de banco de dados e análise sobre protestos e greves no Brasil (2011-2015)
}

\section{Jeniffer Torres Tavares*, Ana Clara Rocha da Costa, Andreia Galvão, Leonardo Joanes da Silva, Lucas dos Anjos Nascimento, Luciana Ferreira Tatagiba \\ Resumo}

Este projeto tem por objetivo levantar dados sobre manifestações e protestos no Brasil no ano de 2012, sendo esse período correspondente ao segundo ano do governo Dilma Rousseff (PT). Para a realização deste projeto foi utilizado a elaboração e montagem de um banco de dados com informações coletadas através de jornais.

\section{Palavras-chave:}

Protestos, greves, movimentos sociais

\section{Introdução}

O projeto de montagem do banco de dados sobre protestos e greves no ano de 2012 se insere em um projeto maior que abrange os anos de 2011 a 2015, deste modo estando inserido no período do governo da presidenta Dilma Rousseff. $\mathrm{O}$ banco de dados permite $\mathrm{O}$ mapeamento dos conflitos ocorridos durante o período em questão através do levantamento de informações importantes tais quais o tipo de protesto, organizações que chamam o protesto, número de detidos, feridos etc. O banco de dados tem por objetivo coletar tais informações sobre os protestos no Brasil no período que abrange o ano de 2012, podendo futuramente ser utilizado como fonte de dados para outras pesquisas que necessitem informações sobre os protestos ocorridos no Brasil.

\section{Resultados e Discussão}

O processo de elaboração da estrutura do banco de dados foi um momento importante do projeto, já que pra isso foi preciso definir quais informações significativas para o banco de dados poderiamos recolher nas noticias de jornal, de modo a nos possibilitar a visualização de características importantes no desdobramento dos protestos dos anos em questão. A discussão sobre a elaboração do banco se deteve grande parte em encontrar variáveis que se encaixassem nos mais diversos tipos de protestos com os quais estavamos trabalhando, mas que ao mesmo tempo não se tornasse muito superficial e que nos permitisse obter informações relevantes sobre os acontecimentos noticiados no jornal, fossem essas informações sobre greves, ocupações, marchas, etc. O banco de dados foi alterado em diversos momentos durante a coleta de dados, até que obtivemos como resultado um banco que conseguisse nos proporcionar informações relevantes para uma futura análise dos dados.

Para a coleta de dados foram utilizadas algumas sessões do jornal Folha de São Paulo, sendo essas Primeiro Caderno, Mercado e Cotidiano onde era possível levantar informações sobre manifestações e protestos no Brasil durante o ano de 2012.

A escolha do jornal Folha de São Paulo ocorre por este ser um jornal de grande circulação e proporcionar o acesso a notícias que abrangem todo o território nacional.

\section{Conclusão}

A elaboração do banco de dados se mostrou uma tarefa difícil, levando a diversas reestruturações. No entanto acreditamos ter atingido o objetivo inicial de criar um banco de dados capaz de disponibilizar a futuras pesquisas um material que proporcionará consultas elaboradas e permitirá um estudo compreeensivo do periodo.

\section{Agradecimentos}

Agradeço ao PIBIC/SAE pelo apoio financeiro, às professoras Luciana Ferreira Tatagiba e Andreia Galvão pela condução do projeto, à professora Andreia Freitas pela apoio técnico na produçào do banco de dados e aos membros do projeto. 